\title{
Determinants of Social Entrepreneurs in Southeast Europe: GEM Data Analysis
}

\author{
Bojan Leković $^{1, *}$, Ozren Uzelac ${ }^{1}$, Tibor Fazekaš ${ }^{2}$, Aleksandra Marcikić Horvat ${ }^{3(\mathbb{D}}$ and Petar Vrgović ${ }^{4}(\mathbb{D}$ \\ 1 Department of Management, Faculty of Economics in Subotica, University of Novi Sad, \\ 21000 Novi Sad, Serbia; ozren.uzelac@ef.uns.ac.rs \\ 2 City Administration-City of Subotica, 24000 Subotica, Serbia; ftibi@gmail.com \\ 3 Department of Business Informatics and Quantitative Economics, Faculty of Economics in Subotica, \\ University of Novi Sad, 21000 Novi Sad, Serbia; aleksandra.marcikic.horvat@ef.uns.ac.rs \\ 4 Department of Industrial Engineering and Management, Faculty of Technical Sciences, University of Novi \\ Sad, 21000 Novi Sad, Serbia; vrgovic@uns.ac.rs \\ * Correspondence: bojan.lekovic@ef.uns.ac.rs; Tel.: +381-24-628-143
}

Citation: Leković, B.; Uzelac, O.; Fazekaš, T.; Horvat, A.M.; Vrgović, P. Determinants of Social Entrepreneurs in Southeast Europe: GEM Data Analysis. Sustainability 2021, 13, 11513. https://doi.org/10.3390/ su132011513

Academic Editor: João J. Ferreira

Received: 5 September 2021

Accepted: 14 October 2021

Published: 18 October 2021

Publisher's Note: MDPI stays neutral with regard to jurisdictional claims in published maps and institutional affiliations.

Copyright: (c) 2021 by the authors. Licensee MDPI, Basel, Switzerland. This article is an open access article distributed under the terms and conditions of the Creative Commons Attribution (CC BY) license (https:// creativecommons.org/licenses/by/ $4.0 /)$.

\begin{abstract}
With this paper, we aim to examine the relationship between cognitive, social, and demographical factors, as well as national culture and its relationship with social entrepreneurial activity in Southeast Europe (SEE). The empirical research employs a binary logistic regression model, utilizing data obtained from the Global Entrepreneurship Monitor. For the purpose of the empirical research, we selected a sample of early-stage entrepreneurs who founded their businesses in Hungary, Romania, Slovenia, Croatia, or North Macedonia. The research sample in these five countries includes 10,012 examinees, of which 615 are social entrepreneurs. A statistically significant relationship was identified between observed phenomena in terms of entrepreneurial networking, risk aversion, individualism, entrepreneurial social image, media impact, gender, work status, and education. The results can be explained by the specific entrepreneurial context of the SEE region. We also point out recommendations for future research.
\end{abstract}

Keywords: social entrepreneurship; cognitive and social factors; demographic; national culture

\section{Introduction}

In recent years, the number of works focused on the discipline of entrepreneurship increased [1-4]. Research in the field of entrepreneurship includes different perspectives. One of the more dominant approaches is certainly the link between entrepreneurship and its impact on countries' economic growth [5], and thus on social well-being as well as employment growth, based on entrepreneurial activity as a generator of job creation. In this way, space is opened for the so-called social entrepreneurs, who represent new economic agents in economic activity. Therefore, the importance of social entrepreneurship in social, cultural, and economic terms is increasingly acknowledged [6]. Although the concept of social entrepreneurship has gained increased recognition and deserved importance, there is still a surprising lack of understanding of the prevalence and drivers of this type of entrepreneurial activity [7]. What intrigued researchers were individual drivers, at the micro-level, and country drivers, at the macro-level [8,9]. Taking into account previous research aimed at identifying different generators of social entrepreneurship, we aimed to conduct an explanatory analysis to evaluate the antecedents of this type of entrepreneurial behavior. The field of social entrepreneurship is dominated by theoretical versus empirical research [10]. Due to the evident lack of research in this area at the SEE (Southeast Europe) level, this empirical research was conducted to extend our knowledge of social entrepreneurs in this region. At the same time, we sought to answer the question of what are the ambient conditions that lead to the emergence of this type of entrepreneurial behavior at the level of national economies, as well as the characteristics of individuals that 
can be attributed to social entrepreneurs. The empirical data were collected from social entrepreneurs (nascent entrepreneurs and new business owners) who are involved in business in Croatia, Hungary, North Macedonia, Slovenia, and Romania. A researcher's focus on the SEE region may be explained by a general tendency to improve entrepreneurial activity in these countries, discovering the importance and potential of social entrepreneurship and its impact on general activity. What particularly interested the authors of this paper are the generators of social entrepreneurship. Since most research does not fully examine the antecedents of social entrepreneurial activity [11], the authors of this paper sought to fill this gap in the literature, taking into account the suggestions of individual researchers in terms of the influence of national culture [12,13] and cognitive [14], social [15], and demographic factors [16]. Our aim is to acquire knowledge of how values and beliefs and cognitive, social and demographic characteristics shape an individual to accomplish a social mission through social entrepreneurial activity.

This study is structured as follows: the section on the theoretical background outlines the research problems and presents the set of hypotheses, followed by the second section, research methodology, which gives an overview of variables used in research and a presentation of statistical data analyses. The paper ends with a discussion of the empirical results and conclusion about some implications and limitations of this paper.

\section{Literature Review}

Recently, social entrepreneurship has been attracting a lot of attention from numerous researchers, primarily due to its focus on solving problems of a global nature [17]. The emergence of social entrepreneurship has been explained at the macro level by respecting socio-economic drivers, at the meso level by exploring concepts such as opportunity, and at the micro-level by investigating entrepreneurial activity [18]. What is noticeable and permeates the available literature in this area is the lack of homogeneity of available definitions of social entrepreneurship. Nevertheless, the common thread of all definitions can be represented in several elements that best illustrate this discipline. Some of them are creating social value through market-based initiatives [19]; facilitating social needs through innovative approach [20]; and activities to discover, define, and exploit opportunities to enhance social wealth by creating new ventures or managing existing organizations in an innovative manner [21]. Achieving social needs with problem-solving opportunities can be recognized as a common element within the most definitions.

A number of research papers covering the concept of social entrepreneurship are aimed at pointing out this concept as a distinctive approach concerning commercial entrepreneurship. Taking into account the consulted views, three criteria can be noticed that indicate the distinctiveness of the discipline of social entrepreneurship: social mission, the importance of innovation, and the role of earned income [22]. Social entrepreneurial ventures must have a clear and unambiguous social goal [23] as a pronounced priority of the venture, innovative product, or service [24] as an innovative solution to complex social phenomena, and earned income [25] as a result of being exposed to market logic. Starting from the definition of entrepreneurship defined through three related components-innovativeness, risk-taking, and proactiveness [26] —we also point to the elements of entrepreneurial activity [27] which can be understood as an individual aspiration to engage in entrepreneurial activities. Since social entrepreneurship strives to meet both social and commercial goals, in addition to entrepreneurship, attention is paid to the social activity of individuals, which can be presented as an intention to satisfy societal needs and to profit from collective interests [11].

\subsection{National Culture and Social Entrepreneurial Activity}

One of the factors influencing the formation of social entrepreneurial activity can be recognized in national culture. In recent years, an increasing number of studies have unequivocally confirmed this causal relationship [28,29]. According to Hofstede [30], culture can be defined as the collective programming of the mind which distinguishes the 
members of one group or category of people from another. This does not necessarily mean that all members of one society have the same pattern of behavior. Certainly, there are differences between the behaviors of individuals, but in some cultures, these differences are less noticeable and in others they are more pronounced. Speaking about the national culture and its shaping of the attitudes of individuals, as well as entrepreneurial activity, it is important to mention its dimensions. Observing the literature in the field of entrepreneurship, Hofstede's work is a generally accepted and the most commonly used approach for expressing cultural values [31] and acknowledges the existence of four dimensions: individualism, masculinity, uncertainty avoidance, and power distance.

Individualistic societies, opposite to collectivist societies, have a more pronounced motivation of individuals to achieve their goals, and thus a sense of satisfaction and pride in the results achieved. Within the individualistic culture, the individual takes care of himself or herself and his or her closest family members, while within the collectivist culture, the care of the individual is expected by the group to which loyalty is expressed. Although the results of the research on the impact of individualism on entrepreneurial activity are mixed, the results that indicate a positive relationship dominate [31-33] When it comes to social entrepreneurship, additional vigilance is needed, as the social mission is aimed at creating benefits for society as a whole. Therefore, collectivist societies can be seen as more responsive when it comes to social entrepreneurial activity. Respecting the research view of Puumalainen et al. [34], that the effect of individualism may be different for social entrepreneurship because highly individualistic cultures would be less likely to recognize the social problems, we can expect a negative relationship of the observed variables. What separates masculinity from femininity society is assertiveness opposite to a concern. A positive relationship was identified in the relationship between masculinity and entrepreneurship in terms of commercial entrepreneurship. Characteristics of a maledominated society are high goals and hard work towards achieving them, while for societies characterized by femininity, more attention is paid to the quality of social relationships and job security [35]. When it comes to social entrepreneurship, the likelihood of greater activity will be in less masculine societies. In two other dimensions of national culture, due to their specificity, a negative relationship with entrepreneurship is expected. First of all, uncertainty avoidance can be recognized as the extent to which people feel threatened by uncertain or ambiguous situations [27]. A high level of uncertainty avoidance will lead to a lower degree of risk-taking by individuals, and vice versa. Since risk-taking is one of the key individual characteristics of an entrepreneur, the influence of uncertainty avoidance on entrepreneurial activity is unambiguous [36]. Since, according to Schumpeter [37], risk taking and creative destruction are obligatory elements of entrepreneurship, it is more likely that a high degree of uncertainty affects reduced entrepreneurial activity, and thus social entrepreneurial activity. Power distance indicates the distribution of influence within a society and the distance of individuals from the centers of power. As well as uncertainty avoidance, power distance is also in a negative relationship with entrepreneurial activity. It is understood that one society strives for an equal distribution of power distance. If there is a higher power distance within a society, we are talking about a rigid society that limits vertical social mobility. Moreover, access to resources, formal business networks, knowledge and skills, and even information becomes unattainable, while in cultures with a lower power distance, key elements for a strong entrepreneurial activity are more accessible. The characteristics of social entrepreneurs imply that cultures with low power distance would be more receptive to social entrepreneurship than ones with high power distance [38]. Based on these above-presented views, we defined the following hypothesis:

Hypothesis H1. Perception of entrepreneurial national culture is positively related to social entrepreneurial activity in terms of media impact and entrepreneurs' social image; at the same time, it is negatively related in terms of individualism. 


\subsection{Cognitive and Social Capital Factors and Social Entrepreneurial Activity}

Studies covering the area of knowledge and skills required to start an entrepreneurial venture by an individual are evident [39]. Recognizing the existence of many factors observed in the existing literature, and primarily guided by GEM research, the focus is on networking, entrepreneurial alertness as the perception of existing opportunities in entrepreneurship, entrepreneurial self-confidence based on the perception of their knowledge and skills, and fear of failure as an aversion to risk. Networking ability as a personal skill is essential for entrepreneurs and their ventures. By managing their venture, entrepreneurs develop different types of networks, both formal and informal [40]. Due to the nature of the social entrepreneurial venture, this group of entrepreneurs requires more intensive use of networking [41]. From the formed networks, they draw social capital. Often, networks can serve as a means of overcoming the problem of lack of resources, especially if it is a network made up of social entrepreneurs. In addition to social vision, sustainability, innovation, and financial returns, they are considered the fifth constitutive dimension of social entrepreneurship [42]. Entrepreneurial alertness is an ability of a person to perceive and exploit business opportunities [43]. Since social entrepreneurship is based on solving a societal problem, noticing numerous problems that are in the environment, we can say that social entrepreneurs are surrounded daily by numerous opportunities. Possession of this characteristic indicates the opportunity-driven motivation of individuals, which is of great importance especially in the early stages of a business venture [44] as it allows for a higher venture survival rate. Not only does entrepreneurial alertness have the greatest impact on creating an entrepreneurial venture [45], but perceived business opportunities shape the form and direction of an entrepreneurial venture, especially early-stage entrepreneurial ventures [46]. Entrepreneurial self-confidence is supported by psychological approaches, applied in the field of management. Defined as the person's belief in accomplishing certain tasks and behaviors [47], it can encourage an individual to start an entrepreneurial venture, especially if self-confidence is based on entrepreneurial skills [48] and knowledge [49]. Entrepreneurial self-confidence is based on the Theory of Planned Behavior, which suggests that the appraisal of entrepreneurial knowledge, skills, and experience might have a direct influence on entrepreneurial intentions since they might encourage entrepreneurial behavior. A higher level of self-confidence increases the chances of starting a social entrepreneurial venture [50] since they have higher beliefs in their knowledge and skills that are necessary for solving social problems. Fear of failure is the most frequently mentioned barrier, which is considered a phenomenon related to entrepreneurial business. It can be understood as a negative emotion of an individual that discourages an individual when deciding to start an entrepreneurial venture. Emotional experience as an outcome of the fear of failure activity diminishes entrepreneurial intention for starting a new business, hampering the self-efficacy of potential entrepreneurs [51]. Starting a social entrepreneurial venture, like any other commercial entrepreneurial venture, is accompanied by risk. When it comes to social entrepreneurs, risk aversion is very recognized in its literature [21]. By solving a societal problem, there is a danger of betraying themselves but also the community whose problem is the focus of solving. Recognizing the importance of solving problems, they notice their role and the importance of managing an entrepreneurial venture. Based on the previously presented views, the authors of the paper defined the following hypothesis:

Hypothesis H2. Cognitive and social capital factors (self-confidence, networking) are positively related to social entrepreneurial activity, while at the same time, fear of failure is negatively related to social entrepreneurial activity.

\subsection{Demographic Factors and Social Entrepreneurial Activity}

Demographic variables such as age, gender, income, level of education, and marital status have also been identified as factors that may influence entrepreneurship intentions [52]. Looking at age, younger entrepreneurs are primarily driven by financial and 
independence motives, have fewer family and other responsibilities, strive for business careers, want to take advantage of business opportunities, and have a good perception [53]. Older entrepreneurs, aged 45 and over, have a strong desire to look for new opportunities and business opportunities. They have fewer responsibilities (family responsibilities, raising children, etc.), and are more committed to entrepreneurial activities [49,54]. However, when it comes to starting a social entrepreneurial venture, although an older group of people show greater civic engagement, it is still younger entrepreneurs who initiate this type of venture [55] as they find it easier to accept and apply this concept. When it comes to the gender of entrepreneurs, it can be pointed out that women entrepreneurs face specific barriers that limit their business ventures [56]. In early-stage entrepreneurial ventures, women are more guided by necessary motives of a nonfinancial nature [57] and earn less financial income compared to men [58]. Men believe that they are more desirable candidates for entrepreneurs [59]. Despite the increasing involvement of women in starting entrepreneurial ventures, the influence of male entrepreneurs in commercial entrepreneurship is still dominant [60]. Although the literature on the impact of gender on the start-up of social entrepreneurial ventures is deficient, the results of the study highlight an ever-smaller gender difference in social entrepreneurship as opposed to commercial entrepreneurship [61]. In most research, which seeks an answer to the question of who initiates social entrepreneurial ventures, due to its specific endeavor, the answer is mainly women [62]. One of the biggest myths about entrepreneurship refers to the dilemma of whether entrepreneurs are born or created. Authors Gorji and Rahimian [63] agree with the existence of this myth, emphasizing that entrepreneurial knowledge and skills, and thus starting a business, can be acquired through academic education. Certainly, education has a positive impact on the adoption and development of entrepreneurial knowledge and skills, which separates successful from unsuccessful entrepreneurs. When it comes to education, a high dose of caution is needed, primarily due to the ambiguous results that appear in research, which move on both sides of the continuum, from positive to negative impact. When it comes to social entrepreneurial ventures, several studies unequivocally confirm the existence of a positive relationship between the observed phenomena [16,55]. When it comes to employment status, a full-time job can certainly be seen as a barrier to starting an entrepreneurial venture primarily because of the time it takes to dedicate to that job. However, on the other hand, individuals who are employed either full-time or part-time acquire knowledge and skills as well as work experience that can be crucial for them to start an entrepreneurial venture. In developed countries, it is normal to embark on entrepreneurial ventures to provide additional income, besides a basic salary [64]. Speaking of a social entrepreneurial venture, observing very interesting data from the conducted research, one can see the tendency of conducting early-stage social entrepreneurial ventures by full-time employees, while, when it comes to established ventures, they are led by part-time employees [65].

Hypothesis H3. Demographic factors (age, gender, education, work status) are positively related to social entrepreneurial activity.

\section{Materials and Methods}

\subsection{Sample and Data Collection}

The research is based on the data of the Global Entrepreneurship Monitor (GEM), whose mission is to contribute to the global development of the economy through research in the field of entrepreneurship. It strives to improve knowledge about entrepreneurship by uniting the results and conclusions of research from around the world. GEM was formed in 1997, and its first study was conducted in 1999, under the direction of Paul Reynolds. The Global Entrepreneurship Research Association (GERA) was formed in 2004 as the oversight body of GEM. GERA is a non-profit organization whose mission is to contribute to the global development of the economy by contributing to the research part of entrepreneurship. It seeks to improve knowledge about entrepreneurship by combining 
the results and conclusions of research from around the world: it measures the factors that affect entrepreneurial activity, provides assistance in identifying national policies to develop entrepreneurship at the national and global level, and affects the growth of theoretical and practical knowledge in the field of entrepreneurship. GEM points out that entrepreneurship is any attempt to start a business and new business ventures; it includes owners and managers of new companies, the expansion of existing business run by individual entrepreneurs and a selected team, as well as entrepreneurs who have run the business for many years. GEM data published the data open to the general public only three years after the survey was conducted (the database for 2015 became available in February 2019). The subjects of research in this paper are nascent entrepreneurs and owners and managers of new ventures in the early stages of entrepreneurial activity, with social, environmental, or community objectives, recognized as a social entrepreneurial activity. Any kind of activity, organization, or initiative that has a particular social, environmental, or community objective is recognized by GEM as a social entrepreneurial activity (SEA). According to the GEM methodology, nascent entrepreneurs and new business owners are both part of this unique entrepreneurial phase-the Total Early Activity stage (TEA) [66]. TEA is a combination of entrepreneurs in the phase that combines the stages before the start of a business-nascent entrepreneurs (who set up their business and pay the wages for at least 3 months) —and the stage after nascent entrepreneurship_owners / managers of a new firm (who have paid wages for a continuous period of 42 months). For the research, the GEM database Adult Population Survey from 2015 [67] was used, since the discipline of social entrepreneurship was represented as a special topic that year. For the needs of the research covering the SEE territory, the database was filtered, and the following countries were included in the research sample: Hungary, Romania, Slovenia, Croatia, and North Macedonia. Since the minimum number of respondents per country is 2000, the research sample in these five countries is 10,012, of which 615 are social entrepreneurs.

\subsection{Dependent Variable}

To classify an individual respondent as an entrepreneur, we used the question "Are you, alone or with others, currently trying to start or currently leading any kind of activity that has a social, environmental, or community objective?" [8,14,22,61,68]. Respondents who gave answers (1) Yes, currently trying to start; (2) Yes, currently leading; and (3) Yes, trying to start and leading, were recognized as social entrepreneurs. Contrary to these answers, there was also the possibility, (4) No, which indicated the absence of social entrepreneurial activity. Since the first three responses included TEA entrepreneurs (observed by phases), the variable was recorded. For this reason, answers 1, 2, and 3 were recoded as 1 , while answer 4 was recoded as 2 . Thus, a binary dependent variable was created.

\subsection{Independent Variables}

The group of cognitive and social capital factors includes risk aversion, perceived capabilities, and social networks (networking). Data related to this group of factors were collected by the following questions: "Would fear of failure prevent you from starting a business?" (fearfail); "Do you have the knowledge, skill, and experience required to start a new business?" (suskill); "Do you know someone personally who started a business in the past 2 years?" (knowent). Based on these questions, categorical variables were created, where the value 0 referred to the respondents with the answer "No" and "1" otherwise. The perception of national culture referred to the equal standard of living, media coverage, and social initiative. Data relating to this group of factors were collected by responses to the following statements: "In my country, most people would prefer that everyone had a similar standard of living" (equalinc); "In my country, you will often see stories in the public media and/or internet about successful new businesses" (nbmedia); "In my country, you will often see businesses that primarily aim to solve social problems" (nbsocent). Based on these questions, categorical variables were created, where the value 0 referred 
to respondents with the answers "No" and " 1 " otherwise. In the case of the variable socent, the respondents who refused to answer this question were excluded, leaving three answers: (-1) Don't know; (1) No; and (2) Yes. Demographic factors are made up of age (age.recoded), gender (gender), education (GEMEDUC), and work status (GEMWORK). Data related to this group of factors were collected by the following questions: "Would you be willing to indicate the range that best describes your age?" Potential responses were: (1) below 18; (2) 18-24; (3) 25-34; (4) 35-44; (5) 45-54; (6) 55-64; and (7) 65-99. To make the results more comparable with other research, we created a new categorical variable by recoding. Responses 1, 2, 3, and 4 gained a new value (1) and responses 5, 6, and 7 gained a value (2). When it comes to gender, male respondents are marked with value (1) and females with value (2). The education of individuals is expressed through four responses: (111) Some secondary; (1212) Secondary degree; (1316) Post-secondary; (1720) and Graduate experience. The last variable in the field of demographic factors refers to work status, which is expressed through several categories: (1) Full: full- or part-time; (2) Part-time only; (3) Retired, disabled; (4) Homemaker; (5) Student; (6) Not working;

(7) Other.

\section{Research Results}

An overview of the research sample, which included 615 social entrepreneurs, is given in Table 1, which includes the demographic data, providing more information on the number and percentage of social entrepreneurs in terms of their age, gender, education, and employment status.

Table 1. Descriptive statistics of research sample (demographics).

\begin{tabular}{|c|c|c|c|c|c|}
\hline \multicolumn{6}{|c|}{ Age } \\
\hline & $\begin{array}{c}18-44 \\
350(56.91 \%)\end{array}$ & & \multicolumn{3}{|c|}{$\begin{array}{c}45+ \\
265(43.09 \%)\end{array}$} \\
\hline \multicolumn{6}{|c|}{ Gender } \\
\hline & $\begin{array}{c}\text { Male } \\
302(49.10 \%)\end{array}$ & & & $\begin{array}{l}\text { emale } \\
(50.90 \%)\end{array}$ & \\
\hline \multicolumn{6}{|c|}{ Education } \\
\hline $\begin{array}{c}\text { None } \\
34(5.55 \%)\end{array}$ & $\begin{array}{c}\text { Some secondary } \\
72(11.77 \%)\end{array}$ & $\begin{array}{r}\text { Seco } \\
2\end{array}$ & ee & $\begin{array}{l}\text { ondary } \\
.32 \%)\end{array}$ & $\begin{array}{c}\text { Grad exp } \\
77(12.58 \%)\end{array}$ \\
\hline \multicolumn{6}{|c|}{ Work Status } \\
\hline $\begin{array}{c}\text { Full time } \\
408(67.32 \%)\end{array}$ & $\begin{array}{l}\text { Part time } \\
40(6.60 \%)\end{array}$ & $\begin{array}{c}\text { Retired } \\
64(10.56 \%)\end{array}$ & $\begin{array}{c}\text { Homemaker } \\
9(1.49 \%)\end{array}$ & $\begin{array}{c}\text { Student } \\
23(3.79 \%)\end{array}$ & $\begin{array}{c}\text { Not working } \\
62(10.24 \%)\end{array}$ \\
\hline
\end{tabular}

The binary logistic regression model was used to understand the influence of different categorical independent variables on the intention to start the business as the dependent variable. The Omnibus test of model coefficients indicated the $\chi^{2}$ statistic 141.45 and the model was found significant. It can be concluded the overall model predicts the intention to start the business significantly (Table 2).

Table 2. Omnibus tests of model coefficients.

\begin{tabular}{ccccc}
\hline & & Chi-Square & df & Sig. \\
\hline \multirow{3}{*}{ Step 1 } & Step & 141.449 & 20 & 0.000 \\
& Block & 141.449 & 20 & 0.000 \\
& Model & 141.449 & 20 & 0.000 \\
\hline
\end{tabular}

The Hosmer and Lemeshow's goodness-of-fit test statistics (Table 2) indicate the hypothesis that the observed data are significantly different from the predicted values of the model. The value $(p=0.599)$ indicates that the model does not differ significantly and predicts the actual data closely. The binary regression model explained about $4.7 \%$ 
(Nagelkerke R2) of the variance of the dependent variable and correctly classified $93.5 \%$ of cases (Table 3).

Table 3. Hosmer and Lemeshow test, model summary, and classification table.

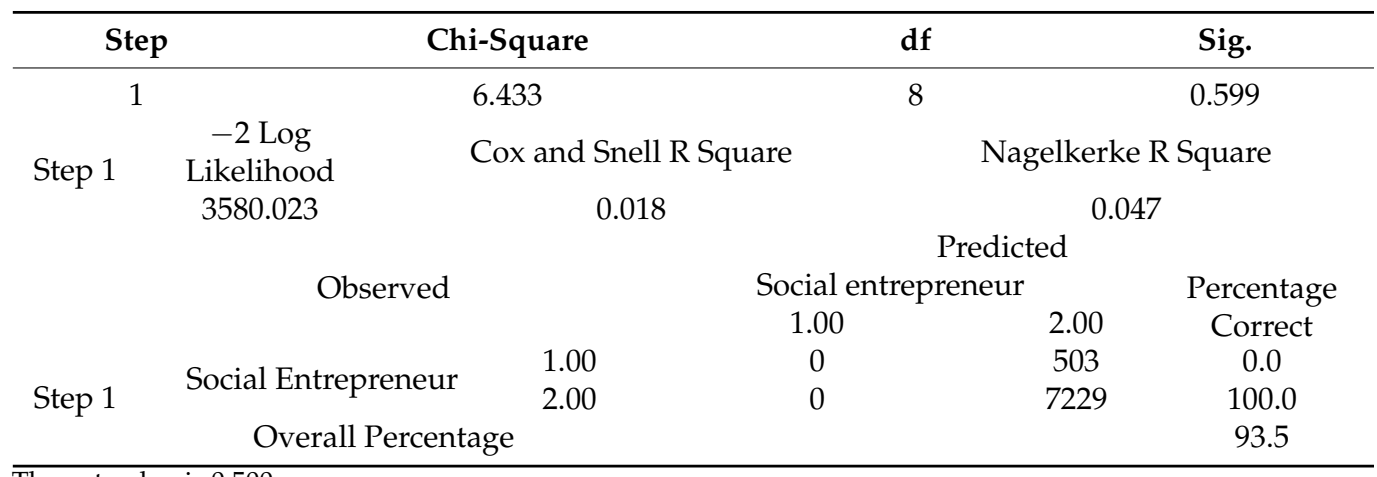

The cut value is 0.500 .

According to the Wald test (used to determine the statistical significance for each of the independent variables), the statistical significance of the test was found, shown in Table 4. Following variables added significantly to the model: (knowent) $p=0.000$; (fearfail) $p=0.004$; (equalinc) $p=0.006$; (nbsocent) $p=0.007$; (nbmedia) $p=0.022$; (gender) $p=0.048$; (GEMWORK) $p=0.003$; (GEMEDUC) $p=0.000$. Other variables such as (suskill) and (age) did not significantly add to the model.

Table 4. Parameter estimates for logistic regression.

\begin{tabular}{|c|c|c|c|c|c|c|}
\hline Variables & B & S.E. & Wald & $\mathrm{df}$ & Sig. & $\operatorname{Exp}(B)$ \\
\hline knowent (networking) & 0.508 & 0.098 & 27.075 & 1 & 0.000 & 1.661 \\
\hline suskill (self-confidence) & 0.186 & 0.100 & 3.468 & 1 & 0.063 & 1.204 \\
\hline fearfail (risk-aversion) & -0.278 & 0.097 & 8.171 & 1 & 0.004 & 0.758 \\
\hline equalinc (individualism) & -0.280 & 0.101 & 7.687 & 1 & 0.006 & 0.756 \\
\hline $\begin{array}{c}\text { nbsocent(social image- }-\mathrm{I} \\
\text { don't know) }\end{array}$ & & & 12.203 & 3 & 0.007 & \\
\hline nbsocent-no & 18.586 & $19,945.386$ & 0.000 & 1 & 0.999 & $117,955,622.7$ \\
\hline nbsocent-yes & 1.160 & 0.332 & 12.203 & 1 & 0.000 & 3.190 \\
\hline nbmedia (media impact) & -0.220 & 0.096 & 5.233 & 1 & 0.022 & 0.802 \\
\hline age.recoded (age) & 0.073 & 0.103 & 0.493 & 1 & 0.483 & 1.075 \\
\hline gender (gender) & 0.190 & 0.096 & 3.900 & 1 & 0.048 & 1.209 \\
\hline $\begin{array}{l}\text { GEMWORK (work } \\
\text { status_full time) }\end{array}$ & & & 17.877 & 5 & 0.003 & \\
\hline GEMWORK (part time) & -0.152 & 0.163 & 0.867 & 1 & 0.352 & 0.859 \\
\hline GEMWORK (retired) & -0.673 & 0.234 & 8.295 & 1 & 0.004 & 0.510 \\
\hline $\begin{array}{l}\text { GEMWORK } \\
\text { (homemaker) }\end{array}$ & -0.108 & 0.213 & 0.254 & 1 & 0.614 & 0.898 \\
\hline GEMWORK (student) & 0.934 & 0.414 & 5.088 & 1 & 0.024 & 2.544 \\
\hline $\begin{array}{l}\text { GEMWORK (not } \\
\text { working) }\end{array}$ & -0.301 & 0.276 & 1.187 & 1 & 0.276 & 0.740 \\
\hline $\begin{array}{c}\text { GEMEDUC } \\
\text { (education-none) }\end{array}$ & & & 21.929 & 4 & 0.000 & \\
\hline $\begin{array}{l}\text { GEMEDUC (some } \\
\text { secondary) }\end{array}$ & 0.220 & 0.251 & 0.765 & 1 & 0.382 & 1.246 \\
\hline GEMEDUC (secondary) & 0.250 & 0.204 & 1.507 & 1 & 0.220 & 1.284 \\
\hline $\begin{array}{c}\text { GEMEDUC } \\
\text { (post-secondary) }\end{array}$ & 0.680 & 0.166 & 16.816 & 1 & 0.000 & 1.973 \\
\hline GEMEDUC (grad exp) & 0.456 & 0.162 & 7.919 & 1 & 0.005 & 1.578 \\
\hline Constant & 2.123 & 0.261 & 66.165 & 1 & 0.000 & 8.359 \\
\hline
\end{tabular}

According to the probability of an event occurring based on a one-unit change in an independent variable, we can highlight that the odds of starting and currently leading 
a social entrepreneurial venture are 1.661 times greater for respondents who express a positive attitude when it comes to networking. When it comes to risk aversion, we can highlight that the odds of starting and currently leading a social entrepreneurial venture are 0.758 times smaller or $24.2 \%$ less for respondents who express the fear of failure. According to the probability of an event occurring based on a one-unit change in an independent variable, we can highlight that the odds of starting and currently leading a social entrepreneurial venture are 3.190 times greater for respondents who recognized social entrepreneurial activity in their country concerning the respondents who expressed "I don't know" as an answer. When it comes to the answer "No", no statistically significant difference was identified concerning the reference category. In the case of representation of entrepreneurship in electronic media, we can highlight that the odds of starting and currently leading a social entrepreneurial venture are 0.802 times smaller or $19.8 \%$ less for respondents who identified entrepreneurship media presence. In the case of a similar standard of living observed as collectivism, we can highlight that the odds of starting and currently leading a social entrepreneurial venture are 0.756 times smaller or $24.4 \%$ less for respondents who express a positive attitude against collectivism. In the genderrelated variable, we emphasize that the odds of starting and currently leading a social entrepreneurial venture are 1.209 times greater for female respondents concerning male respondents. Within the working status of respondents, we can highlight that the odds of starting and currently leading a social entrepreneurial venture are 0.510 times smaller or $49 \%$ less for retired individuals, as well as 2.544 times greater for students concerning full or part time employment. Within the education variable, we emphasize that the odds for starting and currently leading a social entrepreneurial venture are 1.973 times greater for post-secondary and 1.578 times greater for graduate experience concerning the education category "none" (lack of education) as a reference.

\section{Discussion}

This paper examines the effects of national culture, cognitive, social, and demographic factors on social entrepreneurial activity in selected countries of the Southeast Europe region. A social entrepreneurial venture is likely to be influenced by individual characteristics, demographic factors, as well as entrepreneurial culture. The results showed us certain specifics of social entrepreneurs in the mentioned region. Our regression model showed that there are statistically significant relations for all observed variables (similar standard of living, entrepreneur's social image, media impact), but the positive relationship was absent in the case of media impact. Based on these results, our first hypothesis (H1) is partially confirmed. Observing a similar standard of living as collectivism $[10,69]$, regarding entrepreneurship presence in the media as an impact of media as well as businesses to solve social problems as a social image, a positive impact on social entrepreneurial activity has been confirmed in previous studies [70]. Within a collectivist society, subordination to a group and placing the interests of the group above the individual is evident. Based on that, rigidly observed, the collectivist approach should favor the development of a social entrepreneurial venture. The individualistic approach should favor the development of a commercial entrepreneurship venture, which puts individual interests ahead of group ones, and, as such, provokes a negative response from society [71]. However, to start entrepreneurial ventures aimed at solving social problems, entrepreneurial initiative, proactivity, and alertness are needed-everything that adorns an entrepreneur as an individual. For that reason, collectivism, as a pronounced characteristic of society observed through the dimension of national culture, does not imply a higher degree of social entrepreneurial activity, which has been proven in some studies \{13]. Entrepreneurs' social image can be decisive when we talk about social entrepreneurial activity. The results of our research indicate a positive and statistically significant relationship. This result is in line with the results of previous studies [70], indicating a statistically significant and positive relationship between the observed variables, especially in the years marked as the period of economic crisis. This can be explained by the fact of more pronounced social problems in times 
of crisis and the emphasis on the importance of entrepreneurship and entrepreneurs as carriers of economic change and recovery. When it comes to media impact, we expected a positive relationship; however, the results were contrary to expectations but consistent with some studies [22,70] that conducted their research in Spain on two different geographical areas, different cultural and historical heritage, and different development paths, within which the same results appear. One possible explanation may be the greater impact of social media on social enterprises [72,73], which was omitted by the methodology used in this case.

In the case of cognitive and social factors, statistically significant relations were confirmed in the case of risk aversion and social networks. Statistically significant relations were absent in the case of perceived capabilities. Based on these results, we partially proved our second hypothesis (H2). These significant relations have been confirmed in various studies $[14,19,74]$. As expected, as well as in line with the literature, the presence of fear of failure reduces the possibility of being a social entrepreneur. There is a prejudice that social entrepreneurs face less risk compared to commercial ones. Like every other venture, social ones also operate in risky conditions [75], and risk-taking is a very well-known fact in the field of social entrepreneurship [21]. Social entrepreneurs face different types of risks on their way to success. First of all, unlike commercial enterprises, in addition to having to ensure the sustainability of the business, these ventures also have to solve a social problem. Since these ventures are mostly based on an area characterized by the presence of numerous social problems, the potential danger of poor market functioning [76] that may jeopardize financial stability, and thus business sustainability, must be considered. Social entrepreneurs engage various resources intending to achieve primarily social good, and only then the financial return on investment. Because social entrepreneurs have limited sources of income, their contacts and social networks become potential sources to supply the missing resources. In the case of demographic factors, statistically significant relations were confirmed in the case of gender, work status, and education. As we have assumed, these results are in line with consulted literature [19]. Statistically significant relations were absent in the case of the age of the individual. Based on these results, we can highlight that our third hypothesis (H3) is partially confirmed. Women's interest in entering the world of entrepreneurship has undoubtedly increased [77]. Unlike commercial entrepreneurship, where women are underrepresented, their presence is more significant in the social entrepreneurship sector, as evidenced by individual judges who indicated their presence within a national economy at $46 \%$ [78]. Male entrepreneurs are predominantly goal-oriented and financially motivated, which stems from their competitive nature. If we consider care and empathy as characteristics of the female gender and feminine national culture, the logical consequence is a higher probability of women starting social entrepreneurial ventures in these countries, such as the SEE region. In the case of employment status, although being retired does not necessarily mean never working again and there are examples of active individuals in the form of entrepreneurs, there is less probability of this group of individuals when it comes to starting a venture than full or part time employees, whether it is commercial or, as in this case, social entrepreneurship. The data on the participation of the student population as a driver of social entrepreneurial ventures and their higher probability of occurrence are interesting. This can be partly explained by their inactivity on the labor market, i.e., the lack of portability for work, since they are still in the process of acquiring education. These individuals are three times more likely to become social rather than commercial entrepreneurs, which is in line with Harding and Cowling's [55] study. In addition, individuals with graduate and postgraduate degrees have a pronounced tendency to become socially active entrepreneurs. Higher education is considered an important predictor of social entrepreneurial behavior [6], and a higher level of education increases the likelihood of being a social entrepreneur [79]. One of the possible explanations is hidden in the educational process, where the student acquires many entrepreneurial knowledge and skills, how to collaborate and work with a team, how to apply the problem-solving methodology, how to use creativity to find an innovative 
approach to difficult (social) problems. By adopting these skills and creating a mental structure, the students and future entrepreneurs are looking for products and solutions that make the world a better place to live.

\section{Conclusions}

This study contributes both on a theoretical and a practical level. At the theoretical level, this paper enhances the literature by exploring the effects of cognitive, social, and demographic factors, as well as national culture, on social entrepreneurial activity. Embracing research in the context of SEE-a region that is deficient in the number of papers in the field of social entrepreneurship, especially with empirical research-this paper, relying on GEM data, offers an opportunity to understand the emergence of social entrepreneurs in the SEE region. Our current knowledge of social entrepreneurial activity is predominantly based on research results from countries characterized by high income levels, which are prevalent in the literature [19]. These are studies that include highly developed countries in Western Europe. Therefore, the results of research from developing countries, which is characterized by market imperfection and lower availability of financial resources intended for the development of social entrepreneurial activity, are gaining in importance. On a practical level, this study offers an opportunity for practitioners to recognize elements of influence on social entrepreneurial activity, to create policies for its development in the field of networking, education, and gender equality. The authors deal in more detail with specific examples of some implications for practice in the following part of the text. With insight into the various elements of national culture and their positive impact, policymakers can influence social entrepreneurial activity through policymaking and incentives. Moreover, when it comes to cognitive and social factors, the undoubted and most significant contribution to social entrepreneurial activity has been identified as networking. Thus, the results offer a basis for the development of initiatives and associations of social entrepreneurs in the form of clusters whose contribution to social entrepreneurial activity would be unambiguous. The benefits of networking are numerous, from encouraging innovation to facilitating access to the international market, all the way to the growth of an entrepreneurial venture. Insights from demographical factors also offer a foundation for future development measures and policies. The impact of education on social entrepreneurial activity is undoubted, and the level of participation of the student population is very interesting. This opens the possibility for creating teaching content as a mandatory element of the curriculum at different faculties within universities. The topic of social entrepreneurship should permeate all faculties so that it becomes a privilege only for business studies. Moreover, speaking of demographical factors, to break the stereotypes regarding the dominance of men in the world of entrepreneurship, the results suggest opening the space for further empowerment of women social entrepreneurs, focusing on the needs of users and not on the requirements of donors.

When it comes to methodology, certain limitations of the research should be pointed out. First, we achieved a low Nagelkerke coefficient $(4.7 \%)$, which indicates a relatively small percentage of explanations for the phenomenon of social entrepreneurial activity. However, since it is a question of perceiving entrepreneurship as a complex social phenomenon, which is influenced by factors of different levels (from individual to environmental), the result is quite satisfactory. When it comes to GEM databases, the limitation can be caused by cross-sectional data usage. These are data that consider different areas of entrepreneurship (individual, demographic, national culture, etc.) at one point or time. Instead of cross-sectional data, there is potential for panel data usage. The use of panel data has a greater number of observations to ensure that regression analysis and residual values are plausible and reliable [35]. Thus, it is possible to cover a larger period of the observed phenomena, which may change over time. A potential constraint may be the countries covered by the survey. Although there is a sufficient number of respondents within the five observed countries of the SEE region, several countries are missing, so we cannot say with certainty that the results obtained reflect the situation within this region. 
The study included available data from the countries covered by the GEM survey, while the reason for the absence of individual countries (e.g., Bosnia and Herzegovina, Serbia, Montenegro) in this study was their absence in the 2015 GEM survey. On the other hand, these limitations open up future research through the inclusion of a larger number of countries of the SEE region, as well as years of research. Although the countries belong to the same geographical area and region, significant differences and deviations are possible when it comes to the observed phenomena, and a comparative analysis of the countries in the region could be suggested as an upgrade of the research. Separately observed, national culture is not sufficient to explain the rates of social entrepreneurial activity [13]. For this reason, future research may investigate the impact of the environmental (entrepreneurial) conditions prevailing in the observed countries, including the corresponding variables from Entrepreneurial Framework Conditions.

Author Contributions: Four co-authors worked together to the completion of this article. T.F. and A.M.H. were in charge of data collection, software processing, and analyzing the final results. B.L. and O.U. contributed to conceptualization, reviewing and revising the literature, and discussion and conclusions. P.V. participated in writing-review and editing. All authors have read and agreed to the published version of the manuscript.

Funding: This research received no external funding.

Institutional Review Board Statement: Not applicable.

Informed Consent Statement: Not applicable.

Data Availability Statement: Not applicable.

Conflicts of Interest: The authors declare no conflict of interest.

\section{References}

1. Shane, S. Reflections on the 2010 AMR Decade Award: Delivering on the Promise of Entrepreneurship as a Field of Research. Acad. Manag. Rev. 2012, 37, 10-20. [CrossRef]

2. Bae, T.J.; Qian, S.; Miao, C.; Fiet, J.O. The Relationship between Entrepreneurship Education and Entrepreneurial Intentions: A Meta-Analytic Review. Entrep. Theory Pr. 2014, 38, 217-254. [CrossRef]

3. Busenitz, L.W.; Plummer, L.A.; Klotz, A.C.; Shahzad, A.; Rhoads, K. Entrepreneurship Research (1985-2009) and the Emergence of Opportunities. Entrep. Theory Pr. 2014, 38, 1-20. [CrossRef]

4. Lekovic, B.; Vojinovic, Z.; Milutinovic, S. Cooperation as a Mediator between Entrepreneurial Competences and Internationalization of New Venture. Eng. Econ. 2020, 31, 72-83. [CrossRef]

5. Acs, Z.J.; Szerb, L. Entrepreneurship, economic growth and public policy. Small Bus. Econ. 2007, 28, 109-122. [CrossRef]

6. Harding, R. Understanding Social Entrepreneurship. Ind. High. Educ. 2007, 21, 73-84. [CrossRef]

7. Stephan, U.; Uhlaner, L.M.; Stride, C. Institutions and Social Entrepreneurship: The Role of Institutional Voids, Institutional Support, and Institutional Configurations. J. Int. Bus. Stud 2014, 46, 308-331. [CrossRef]

8. Cai, L.; Hughes, M.; Yin, M. The relationship between resource acquisition methods and firm performance in Chi-nese new ventures: The intermediate effect of learning capability. J. Small Bus. Manag. 2014, 52, 365-389. [CrossRef]

9. Hoogendoorn, B. The Prevalence and Determinants of Social Entrepreneurship at the Macro Level. J. Small Bus. Manag. 2016, 54, 278-296. [CrossRef]

10. Canestrino, R.; Ćwiklicki, M.; Magliocca, P.; Pawełek, B. Understanding social entrepreneurship: A cultural per-spective in business research. J. Bus. Res. 2020, 110, 132-143. [CrossRef]

11. Canestrino, R.; Bonfanti, A.; Oliaee, L. Cultural insights of CSI: How do Italian and Iranian firms differ? J. Innov. Entrep. $2015,4,1$. [CrossRef]

12. Griffiths, M.D.; Gundry, L.K.; Kickul, J.R. The socio-political, economic, and cultural determinants of social en-trepreneurship activity: An empirical examination. J. Small Bus. Enterp. Dev. 2013, 20, 341-357. [CrossRef]

13. Kedmenec, I.; Strašek, S. Are some cultures more favourable for social entrepreneurship than others? Econ. Res. -Ekon. Istraživanja 2017, 30, 1461-1476. [CrossRef]

14. Nicolás, C.; Rubio, A.; Fernández-Laviada, A. Cognitive determinants of social entrepreneurship: Variations according to the degree of economic development. J. Soc. Entrep 2018, 9, 154-168. [CrossRef]

15. Méndez-Picazo, M.T.; Galindo-Martín, M.A.; Castaño-Martínez, M.S. Effects of sociocultural and economic factors on social entrepreneurship and sustainable development. J. Innov. Knowl 2021, 6, 69-77. [CrossRef]

16. Bosma, N.; Levie, J. Global Entrepreneurship Monitor-2009 Executive Report; Babson College: Wellesley, MA, USA, 2010. 
17. Agarwal, N.; Chakrabarti, R.; Brem, A.; Bocken, N. Market driving at Bottom of the Pyramid (BoP): An analysis of social enterprises from the healthcare sector. J. Bus. Res. 2018, 86, 234-244. [CrossRef]

18. Dufays, F.; Huybrechts, B. Connecting the dots for social value: A review on social networks and social entrepreneurship. J. Soc. Entrep. 2014, 5, 214-237. [CrossRef]

19. Bacq, S.; Janssen, F. The multiple faces of social entrepreneurship: A review of definitional issues based on geo-graphical and thematic criteria. Entrep. Reg. Dev 2011, 23, 373-403. [CrossRef]

20. Nicholls, A. Social Entrepreneurship: New Models of Sustainable Social Change, 1st ed.; Oxford University Press: New York, NY, USA, 2006.

21. Zahra, S.A.; Gedajlovic, E.; Neubaum, D.O.; Shulman, J.M. A typology of social entrepreneurs: Motives, search processes and ethical challenges. J. Bus. Ventur. 2009, 24, 519-532. [CrossRef]

22. Lepoutre, J.; Justo, R.; Terjesen, S.; Bosma, N. Designing a global standardized methodology for measuring social entrepreneurship activity: The Global Entrepreneurship Monitor social entrepreneurship study. Small Bus. Econ. 2013, 40, 693-714. [CrossRef]

23. Certo, S.T.; Miller, T. Social entrepreneurship: Key issues and concepts. Bus. Hor. 2008, 51, 267-271. [CrossRef]

24. Chell, E.; Nicolopoulou, K.; Karatas-Ozkan, M. Social entrepreneurship and enterprise: International and innovation perspectives. Entrep. Reg. Dev. 2010, 22, 485-493. [CrossRef]

25. Massetti, B.L. The social entrepreneurship matrix as a "tipping point" for economic change. Emerg. Complex. Organ 2008, 10, 1-8.

26. Zahra, S.A. Environment, corporate, entrepreneurship, and financial performance: A taxonomic approach. J. Bus. Ventur. 1993, 8, 319-340. [CrossRef]

27. Caputo, F.; Evangelista, F.; Russo, G. The role of Information sharing and communication strategies for improving stakeholder engagement. In Business Models for Strategic Innovation; Shams, S.M.R., Vrontis, D., Weber, Y., Tsoukatos, E., Eds.; Routledge: Abingdon, UK, 2018; pp. 51-69.

28. Kaasa, A.; Vadi, M. How does culture contribute to innovation? Evidence from European countries. Econ. Innov. New Technol. 2010, 19, 583-604. [CrossRef]

29. Parjanen, S. Experiencing Creativity in the Organization: From Individual Creativity to Collective Creativity. Interdiscip. J. Inf. Knowl. Manag. 2012, 7, 109-128. [CrossRef]

30. Hofstede, G. Cultures and Organizations: Software of the Mind; McGraw-Hill: London, UK, 1991.

31. Terjesen, S.; Hessels, J.; Li, D. Comparative international entrepreneurship: A review and research agenda. J. Manag. 2016, 42, 299-344. [CrossRef]

32. Hartog, J.; Van Praag, M.; Van Der Sluis, J. If You Are So Smart, Why Aren't You an Entrepreneur? Returns to Cognitive and Social Ability: Entrepreneurs Versus Employees. J. Econ. Manag. Strat. 2010, 19, 947-989. [CrossRef]

33. Pinillos, M.J.; Reyes, L. Relationship between individualist-collectivist culture and entrepreneurial activity: Evidence from Global Entrepreneurship Monitor data. Small Bus. Econ 2011, 37, 23-37. [CrossRef]

34. Puumalainen, K.; Sjögrén, H.; Syrjä, P.; Barraket, J. Comparing social entrepreneurship across nations: An exploratory study of institutional effects. Can. J. Adm. Sci. Rev. Can. Sci. l'Administration 2015, 32, 276-287. [CrossRef]

35. Leković, B.; Petrović, M. Characteristics of agro-entrepreneurs in Southeast Europe. In Handbook of Research on Agricultural Policy, Rural Development, and Entrepreneurship in Contemporary Economies; IGI Global: Hershey, PA, USA, 2020; pp. 21-42.

36. Hayton, J.C.; George, G.; Zahra, S.A. National Culture and Entrepreneurship: A Review of Behavioral Research. Entrep. Theory Pr. 2002, 26, 33-52. [CrossRef]

37. Schumpeter, J.A. The Theory of Economic Development; Harvard University Press: Cambridge, MA, USA, 1934.

38. Tracey, P.; Phillips, N.; Jarvis, O. Bridging institutional entrepreneurship and the creation of new organizational forms: A multilevel model. Organ. Sci 2011, 22, 60-80. [CrossRef]

39. Mueller, S.L.; Thomas, A.S. Culture and entrepreneurial potential: A nine country study of locus of control and innovativeness. J. Bus. Ventur. 2001, 16, 51-75. [CrossRef]

40. Turkina, E.; Van Assche, A.; Kali, R. Structure and evolution of global cluster networks: Evidence from the aerospace industry. J. Econ. Geogr 2016, 16, 1211-1234. [CrossRef]

41. Hulgård, L.; Spear, R. Social entrepreneurship and the mobilization of social capital in European social enterprises. In Social Enterprise; Routledge: London, UK, 2007; pp. 101-124.

42. Nga, J.K.; Shamuganathan, G. The influence of personality traits and demographic factors on social entrepreneurship start up intentions. J. Bus. Ethics 2010, 95, 259-282.

43. Lall, M.; Shikha, S. Women in family business. In Proceedings of the First Asian Invitational Conference on Family Business at Indian School of Business, Hyderabad, India, 1-3 February 2008.

44. Boudreaux, C.J.; Nikolaev, B.N.; Klein, P. Socio-cognitive traits and entrepreneurship: The moderating role of economic institutions. J. Bus. Ventur. 2018, 34, 178-196. [CrossRef]

45. Nishimura, J.; Tristán, M. Using the theory of planned behavior to predict nascent entrepreneurship. Acad. Rev. Latinoam. De Adm. 2011, 46, 55-71.

46. Dumitru, I.; Dumitru, I. Drivers of entrepreneurial intention in Romania. Rom. J. Econ. -Cast 2018, 21, $157-166$.

47. Salas, E.; Cannon-Bowers, J.A. The science of training: A decade of progress. Annu. Rev. Psychol. 2001, 52, 471-499. [CrossRef] [PubMed] 
48. El-Hadary, E.T. Gender, Perceptual factors, and Entrepreneurial Intention: Evidence from Egypt. Master's Thesis, The American University in Cairo, New Cairo, Egypt, 2018.

49. Stephan, U.; Hart, M.; Mickiewicz, T.; Drews, C.C. Understanding Motivation for Entrepreneurship; Enterprise Research Centre and Aston Business School: London, UK, 2015.

50. Ernst, K. Heart over Mind-An Empirical Analysis of Social Entrepreneurial Intention Formation on the Basis of the Theory of Planned Behaviour. Ph.D. Thesis, University Wuppertal, Wuppertal, Germany, 2018.

51. Mitchell, J.R.; Shepherd, D.A. To think own self be true: Images of self, images of opportunity, and entrepreneurial action. J. Bus. Ventur 2010, 25, 138-154. [CrossRef]

52. Chipeta, E.M.; Surujlal, J.; Koloba, H.A. Influence of gender and age on social entrepreneurship intentions among university students in Gauteng province, South Africa. Gend. Behav. 2016, 14, 6885-6899.

53. Robichaud, Y.; LeBresseur, R.; Nagarajan, K.V. Necessity and Opportunity—driven entrepreneurs in Canada: An Investigation into their Characteristics and an Appraisal of the Role of Gender. J. Applien Bus. Econ 2010, 11, 59-80.

54. Kautonen, T. Understanding the older entrepreneur: Comparing third age and prime age entrepreneurs in Finland. Int. J. Bus. Sci. Appl. Manag 2008, 3, 3-13.

55. Harding, R.; Cowling, M. Social Entrepreneurship Monitor; London Business School: London, UK, 2006.

56. Zahra, S.; Brush, C.; Davidsson, P.; Fiet, J.; Greene, P.; Harrison, R.T.; Lerner, M.; Mason, C.; Meyer, G.; Sohl, J.; et al. (Eds.) Frontiers of Entrepreneurship Research 2004: Proceedings of the Twenty-Fourth Annual Entrepreneurship Research Conference; Babson College: Wellesley, MA, USA, 2004.

57. Watson, J. Comparing the performance of male and female controlled business: Relating outputs to inputs. Entrep. Theory Pract 2002, 26, 91-100. [CrossRef]

58. Cron, W.L.; Gilly, M.C.; Graham, J.L.; Slocum, J.W. Gender differences in pricing of professional services: Implications for income and customer relationships. Organ. Behav. Hum. Decis. Process 2009, 109, 93-105. [CrossRef]

59. Malach-Pines, A.; Schwartz, D. Now you see them, now you don't: Gender differences in entrepreneurship. J. Manag. Psychol 2008, 23, 811-832. [CrossRef]

60. Parker, S.C. The Economics of Entrepreneurship; Cambridge University Press: Cambridge, UK, 2009.

61. Bacq, S.; Hartog, C.; Hoogendoorn, B.; Lepoutre, J. Social and commercial entrepreneurship: Exploring individual and organizational characteristics. Scales Res. Rep. EIM Bus. Policy Res. 2011, 1, 3-49.

62. Levie, J.; Brooksbank, D.; Jones-Evans, D.; Harding, R.; Hart, M. Measuring social entrepreneurship: Lessons from three years of experimentation by the UK global entrepreneurship monitor team. In Proceedings of the Presented at Babson Entrepreneurship Research Conference, Babson Park, FL, USA, 1 January 2006; p. 3.

63. Gorji, M.B.; Rahimian, P. The Study of Barriers to Entrepreneurship in Man and Woman. Aust. J. Busi-Ness Manag. Res 2011, 1, 31-36. [CrossRef]

64. Smallbone, D.; Welter, F. The distinctiveness of entrepreneurship in transition economies. Small Bus. Economics 2001, 16, 249-262. [CrossRef]

65. Cowling, M. Are entrepreneurs different across countries? Appl. Econ. Lett. 2000, 7, 785-799. [CrossRef]

66. Reynolds, P.D.; Hay, M.; Camp, S.M. Global Entrepreneurship Monitor; Kauffman Center for Entrepreneurial Leadership: Kansas City, MO, USA, 1999.

67. Bosma, N.; Schøtt, T.; Terjesen, S.A.; Kew, P. Global entrepreneurship monitor 2015 to 2016: Special topic report on social entrepreneurship. Bus. Soc. Entrep. Ejournal 2016. [CrossRef]

68. Terjesen, S. Social Entrepreneurship amongst Women and Men in the United States; Special Report. 2017; Office of Advocacy, Small Business Administration: Washington, DC, USA, February 2017. Available online: https://cdn.www.nwbc.gov/wp-content/ uploads/2017/02/13134000/Social-entrepreneurship-amongst-women-and-men-in-the-United-States_021617.pdf (accessed on 15 October 2021).

69. Pathak, S.; Muralidharan, E. Informal institutions and their comparative influences on social and commercial entrepreneurship: The role of in-group collectivism and interpersonal trust. J. Small Bus. Manag. 2016, 54, 168-188. [CrossRef]

70. Ferri, E.; Noguera, M.; Urbano, D. The effect of cultural factors on social entrepreneurship: The impact of the eco-nomic downturn in Spain. In Entrepreneurship, Regional Development and Culture; Springer: Cham, Switzerland, 2015; pp. 75-87.

71. Autio, E.; Pathak, S.; Wennberg, K. Consequences of cultural practices for entrepreneurial behaviors. J. Int. Bus. Stud. 2013, 44, 334-362. [CrossRef]

72. El-Den, J.; Adikhari, P.; Adikhari, P. Social media in the service of social entrepreneurship: Identifying factors for better services. J. Adv. Humanit. Soc. Sci. 2017, 3, 105-114.

73. Islam, M.N.; Chitran, V. Social media and social entrepreneurship. In Leveraging Computer-Mediated Marketing Environments; IGI Global: Hershey, PA, USA, 2019; pp. 104-123.

74. Sahasranamam, S.; Nandakumar, M. Individual capital and social entrepreneurship: Role of formal institutions. J. Bus. Res. 2018, 107, 104-117. [CrossRef]

75. Lumpkin, G.T. From legitimacy to impact: Moving the field forward by asking how entrepreneurship informs life. Strat. Entrep. J. 2011, 5, 3-9. [CrossRef]

76. Di Domenico, M.; Haugh, H.; Tracey, P. Social bricolage: Theorizing social value creation in social enterprises. Entrep. Theory Pract. 2010, 34, 681-703. [CrossRef] 
77. Anggadwita, G.; Mulyaningsih, H.D.; Ramadani, V.; Arwiyah, M.H. Women entrepreneurship in Islamic per-spective: A driver for social change. Int. J. Bus. Glob. 2015, 15, 389-404. [CrossRef]

78. Levie, J.; Hart, M. Business and social entrepreneurs in the UK: Gender, context and commitment. Int. J. Gend. Entrep. 2011, 33, 200-217. [CrossRef]

79. Hidalgo, L.F.; Rialp, J.; Urbano, D. Are there really differences between social and commercial entrepreneurship in developing countries? An institutional approach. In Handbook of Research on Smart territories and Entrepreneurial Eco-Systems for Social Innovation and Sustainable Growth; IGI Global: Hershey, PA, USA, 2020; pp. 306-325. 